\title{
Influence of behavioral and dietary aspects on children's oral health
}

\author{
Influência de aspectos comportamentais e alimentares na saúde bucal infantil \\ Influencia de los aspectos conductuales y dietéticos en la salud bucal de los niños
}

Received: 04/08/2021 | Reviewed: 04/21/2021 |Accept: 04/24/2021 | Published: 05/09/2021

Gleice Tibauje Vicente Ramirez

ORCID: https://orcid.org/0000-0003-2050-6685 Universidade Estadual Paulista, Brazil

E-mail: ramirez.tvgleice@gmail.com

Ana Cláudia Okamoto

ORCID: https://orcid.org/0000-0002-8594-9754 Universidade Estadual Paulista, Brazil E-mail: ana.okamoto@unesp.foa

Tânia Adas Saliba

ORCID: https://orcid.org/0000-0003-1327-2913 Universidade Estadual Paulista, Brazil E-mail: tania.saliba@unesp.foa Suzely Adas Saliba Moimaz

ORCID: https://orcid.org/0000-0002-4949-529X Universidade Estadual Paulista, Brazil E-mail: suzely.moimaz@unesp.foa

\begin{abstract}
The purpose of this study was to verify the association of microbiological aspects, behavioral and eating habits that affect the oral health of preschoolers. This is a cross-section of a longitudinal study, with a sample of 42 preschoolers at 30 months of age. A home visit was carried out to conduct an interview on aspects of breastfeeding, early weaning, the child's oral hygiene habits, such as brushing frequency and habits, sharing toothbrushes and kitchen utensils and 24-hour food recall of the preschooler. Was collected $0.5 \mathrm{ml}$ of saliva from the oral floor of the mother and the preschooler using sterile disposable pipettes for culture in a Petri dish. It was observed that there was an association between early weaning $(p=0.046)$ and bottle use $(p=0.018)$ with the presence of caries; however, there was no association between the consumption of sugary foods between meals $(\mathrm{p}=0.302)$. The average colony-forming unit (CFU) / $\mathrm{ml}$ of S. mutans found in the mothers' saliva was 974421 and the preschool was 135341.9. Extracellular polymer was found in the CFU of samples from $61.90 \%$ of mothers and $09.52 \%$ of preschoolers. Eating habits such as early weaning and bottle use were associated with the presence of caries. There was no association between microbiological and behavioral aspects that affect oral health and the consumption of sugary foods between meals with the presence of caries in preschoolers.
\end{abstract}

Keywords: Breastfeeding; Weaning; Child nutrition; Diet cariogenic; Diet records; Streptococcus mutans.

\section{Resumo}

O presente estudo teve como objetivo verificar a associação de aspectos microbiológicos, comportamentais e hábitos alimentares que afetam a saúde bucal de pré-escolares. Este é um corte transversal de um estudo longitudinal, com uma amostra de 42 pré-escolares aos 30 meses de idade. Foi realizada visita domiciliar para realização de entrevista sobre aspectos da amamentação, desmame precoce, hábitos de higiene bucal da criança, como frequência e hábitos de escovação, compartilhamento de escovas de dente e utensílios de cozinha e recordatório alimentar 24 horas do préescolar. Foi coletado $0,5 \mathrm{ml}$ de saliva do assoalho oral da mãe e do pré-escolar por meio de pipetas descartáveis estéreis para cultura em placa de Petri. Observou-se que houve associação entre desmame precoce $(p=0,046)$ e uso de mamadeira $(\mathrm{p}=0,018)$ com a presença de cárie; entretanto, não houve associação entre o consumo de alimentos açucarados entre as refeições $(\mathrm{p}=0,302)$. A unidade formadora de colônias $(\mathrm{UFC})$ média $/ \mathrm{ml}$ de $S$. mutans encontrada na saliva das mães foi 974421 e a pré-escola foi 135341,9. O polímero extracelular foi encontrado nas UFC das amostras de $61,90 \%$ das mães e $09,52 \%$ dos pré-escolares. Hábitos alimentares como desmame precoce e uso de mamadeira estiveram associados à presença de cárie. Não houve associação entre aspectos microbiológicos e comportamentais que afetam a saúde bucal e o consumo de alimentos açucarados entre as refeições com a presença de cárie em pré-escolares.

Palavras-chave: Aleitamento; Desmame; Nutrição da criança; Dieta cariogênica; Registros de dieta; Streptococcus mutans. 


\section{Resumen}

El presente estudio tuvo como objetivo verificar la asociación de aspectos microbiológicos, conductuales y alimentarios que afectan la salud bucal de los preescolares. Este es un corte transversal de un estudio longitudinal, con una muestra de 42 niños en edad preescolar a los 30 meses de edad. Se realizó una visita domiciliaria para realizar una entrevista sobre aspectos de la lactancia materna, el destete precoz, los hábitos de higiene bucal del niño, como la frecuencia y hábitos de cepillado, compartir cepillos de dientes y utensilios de cocina y recuerdo de alimentos 24 horas del preescolar. Se recogieron $0,5 \mathrm{ml}$ de saliva del suelo bucal de la madre y del niño en edad preescolar utilizando pipetas desechables estériles para cultivo en placa de Petri. Se observó que hubo asociación entre el destete temprano $(\mathrm{p}=0.046)$ y el uso de biberón $(\mathrm{p}=0.018)$ con la presencia de caries; sin embargo, no hubo asociación entre el consumo de alimentos azucarados entre comidas $(\mathrm{p}=0.302)$. La unidad formadora de colonias (UFC) promedio / $\mathrm{ml}$ de S. mutans encontrada en la saliva de las madres fue 974421 y la preescolar fue 135341,9. Se encontró polímero extracelular en las UFC de muestras del 61,90\% de las madres y el 09,52\% de los preescolares. Los hábitos alimentarios como el destete temprano y el uso del biberón se asociaron con la presencia de caries. No hubo asociación entre los aspectos microbiológicos y conductuales que afectan la salud bucal y el consumo de alimentos azucarados entre comidas con la presencia de caries en preescolares.

Palabras clave: Lactancia materna; Destete; Nutrición del niño; Dieta cariógena; Registros de dieta; Streptococcus mutans.

\section{Introduction}

Eating is not just about satisfying the need to eat, but eating a variety of foods that provide an energetic and nutritious balance in order to promote and maintain the health and development of the individual, especially in the early years of childhood, because nutritional, demographic, socioeconomic, behavioral and motivational aspects are environmental factors that affect brain growth and development, impacting long-term health (Moreno et al., 2013; Verduci et al., 2019).

Thus, in the first hours of life, the newborn should consume maternal colostrum, rich in proteins, and until the sixth month of life, feed exclusively on breast milk and continue with it in a complementary way for up to two years or more (World Health Organization, 2001). Generally, as of the sixth month, there should be a pasty diet with fruits, legumes, cereals, tubers and meats, for a balanced diet full of macro and micro nutrients, with consumption of larger amounts of fruits, vegetables and greens and lower amount of fats, sugars and salt (Brazil, 2019).

In order to have a better overview of food consumption, there are several meal quality indexes that assess the health determinants of the population and work as a tool to promote quality of life in the long term. As food consumption cannot be measured objectively, researchers need to rely on self-reported methods, such as food records, food recalls or food frequency questionnaires (Gorgulho et al., 2016; Weker et al., 2019). However, the self-report of meals has limitations, as it is the case for under the age of eight, when the report is provided by the child's guardian.

In this sense, the accuracy of food assessment in children depends on the ability of adults to report their food consumption reliably and validly. A well-accepted and easy-to-apply method is the 24-hour food record, in which all meals of the previous day are recorded in detail with quantities of portions and drinks (Gorgulho et al., 2016; Kolodziejczyk, Merchant, \& Norman, 2012; Korkalo et al., 2019; Weker et al., 2019).

The acquisition of healthy habits should start early in the individual's life. In order to perpetuate these practices throughout life and extend them to new generations, the participation of health professionals is required to monitor and encourage changes in lifestyle (Colley et al., 2019; Norlyk, Larsen, \& Kronborg, 2019; Tully et al., 2019).

On the other hand, having a diet excessively rich in carbohydrates, sucrose and lipids has a negative effect on the individual's body; and when this diet is part of one's eating habits early in life, there is a predisposition to chronic noncommunicable diseases, such as diabetes and obesity (Lima et al., 2020; Moreno et al., 2013). In addition, the high frequency of sugary foods ingestion with a low frequency of tooth cleaning and/or brushing interferes with the oral microbiome, contributing with the emergence of oral diseases, such as dental caries breakdowns (Barone et al., 2018; Gibson \& Williams, 1999; Marshall, Broffitt, Eichenberger-Gilmore, Warren, Cunningham, \& Levy, 2005). 
For the newborn, breast milk is the ideal (Marques et al., 2020; Rocha et al., 2010; Sousa et al., 2021). However, there are cases in which breast milk is not considered a sufficient source of food, being supplemented with other substances or formulas, often of high cariogenic potential, through artificial breastfeeding (Barone et al., 2018; Feldens et al., 2018; Nicksic et al., 2018; Rocha et al., 2010; Rocha et al., 2013). Inadequate eating habits, such as the introduction of sweetened substances in the bottle, are related to early colonization by Streptococcus mutans, the main cariogenic bacteria, in the oral cavity of infants (Bernabé et al., 2020; Holgerson et al., 2013; Hwang et al., 2015).

The diet with high sucrose content and the quality and frequency of oral hygiene are fundamental for the occurrence of caries disease (Bernabé et al., 2020; Moynihan et al., 2019). Caries injury is the manifestation of a pathological process that occurs as a result of the interaction between cariogenic bacteria present in the oral cavity, length of stay, dental surfaces and constituents of the diet, especially sucrose (Gibson \& Williams 1999; Moynihan et al., 2019). Evidence suggests that the most likely route of vertical transmission of microorganisms residing in the oral microbiota, which are associated with infectious diseases, such as caries, is from the mother or primary caregiver, to the infant, aggravating the risk factors for caries in early childhood (Barone et al., 2018; Cinar, Christensen, \& Hede, 2011; Gibson \& Williams, 1999; Kassebaum et al., 2017; Marshall et al., 2005; Mattos-Graner et al., 2001).

Since tooth decay is an important global public health problem (Kassebaum et al., 2017) and shares common risk factors, such as diet, and other conditions, with obesity and other health problems (Lima et al., 2020; Moreno et al., 2013), there is a need for collaboration between oral and general health care providers to manage the emergence of diseases resulting from an unbalanced diet, caries and dental disease in preschoolers (Cinar, Christensen, \& Hede, 2011). The purpose of this study was to verify the association of microbiological aspects, behavioral and eating habits that affect the oral health of preschoolers.

\section{Methodology}

\section{Study Design:}

This is a cross-section of a longitudinal study with a sample of 42 preschoolers at 30 months of age.

Statistical analysis of logistic regression and Fisher's exact test were used, with a significance level of $5 \%$.

\subsection{Description of the longitudinal study}

In the month of January to December of the year 2016, the project started with the visit of the team of researchers in all 18 Family Health Units in a municipality in the interior of the state of São Paulo, where only Community Health Agents make visits households.

The pregnant women were selected from the 18 Family Health Units and were in the last trimester of pregnancy. The approach was performed while waiting for prenatal care and consultation with the gynecologist / obstetrician. At that time, the pregnant women answered a questionnaire about the expectation of delivery and the intention and expectation of breastfeeding, in addition to filling out the registration data for home visits that would occur at 6 and 30 months of age.

After the interview, pamphlets were distributed on the encouragement of breastfeeding and installation of healthy oral and food habits for mother and infant, in addition to the reproduction of a motivational video with the same content. At 6 months of age, the families were visited at home to collect data on eating practices and obtain anthropometric data. 


\section{Inclusion and Exclusion Criteria}

The inclusion criteria for infants were: newborns, born at term; newborns who did not present any alteration that would preclude the practice of breastfeeding, who were not born with low weight (below 2500 grams) and non-twin pregnancy.

As exclusion criteria of the participants: the refusal to participate in the research.

The sample calculation was based on the variable rate of exclusive breastfeeding at six months of age in the studied population (Rocha et al., 2013). Calculation for sample size (finite population):

$$
\mathrm{n}=\frac{\mathrm{Z}^{2} \times \mathrm{P} \times \mathrm{Q} \times \mathrm{N}}{\mathrm{e}^{2} \times(\mathrm{N}-1)+\mathrm{Z}^{2} \times \mathrm{P} \times \mathrm{Q}}
$$

Subtitle

Z - 95\% confidence interval - 1.96

P - Rate of exclusive breastfeeding expected at six months of age - 10\%

Q - Percentage of infants not exclusively breastfed at six months - 90\%

$\mathrm{N}$ - Total population of pregnant women in the study period - 725

e - Absolute sampling error - 5\%

Result: 116 pregnant women with a $30 \%$ increase, rounded up to 150 pregnant women.

Sample loss:

The initial sample consisted of 150 mother-infant pairs, during the visit and follow-up phase at 6 months of the infant's life, there was a loss of $50.67 \%$ of the sample, totaling 74 mother-infant pairs. At 30 months of age of the preschooler, the period of the current study, there was a loss of $72 \%$ of the initial sample, corresponding to 42 mother-preschooler in pairs.

The loss of the sample occurred due to changes in address and telephone numbers and cell phones by the families belonging to the study, during the time interval from one phase to another of the research.

\section{Characteristics of the research site}

The research was carried out in a municipality in the state of São Paulo, Brazil, a regional reference for health care, with a population, according to the last sense in 2010, of 181579 inhabitants, and estimated for the year 2019 of 197016 inhabitants, with GDP per capita of R \$35,769.43. Average wage of formal workers of 2.5 minimum wages, with an average infant mortality rate of 11.02 per 1000 live births. The municipality in question has a total of 18 Family Health Units, which offer services in Primary Health Care to the population (IBGE, 2010).

\section{Data Collection}

Training for interviewers and note takers was carried out for two weeks to clarify the project's objectives and methods of application and completion of the data collection instrument. The training aimed to standardize the data collection procedures and the guidelines carried out during home visits.

The interviews aimed to collect nutritional and behavioral data, with questions such as: breastfeeding intent, breastfeeding modality, frequency of breastfeeding, breastfeeding difficulties, oral hygiene habits and bottle use.

\subsection{Cross-sectional description of the longitudinal study}

At 30 months of age, the families were visited at home to conduct an interview about aspects of breastfeeding, early weaning, the preschooler's oral hygiene habits, such as brushing frequency and habits, sharing toothbrushes and kitchen utensils, besides the completion of the 24-hour food recall preschooler. 
The collection, in this phase of the study, took place over a period January to December of the year 2019.

\section{Saliva Collection}

We collected $0.5 \mathrm{ml}$ of saliva from the oral floor of the mother and preschooler, using sterile disposable pipettes in the morning. After collection, the material was transported in polyethylene microtubes on crushed ice, not exceeding the 3-hour period. In the laboratory, the samples underwent serial dilution and aliquots of $0.1 \mathrm{ml}$ were seeded on Mitis Salivarius Bacitracina Sucrose (MSBS) agar, in duplicate, and incubated in microaerophilia, at $37^{\circ} \mathrm{C}$, for 72 hours to count the Colony Forming Units (CFU) of S. mutans.

The data were recorded in a clinical form developed for this study.

This work respected the ethical precepts for research with human beings, established in the Declaration of Helsinki and in Resolution No. 466/12 (Brazil, 2012), with approval by the Ethics and Research Committee on Human Beings (CAAE 15049319.0.0000.5420).

The authors have no conflicts of interest.

\section{Results}

According to the parents' report, the sharing of kitchen utensils occurs daily, since meals are eaten on the same plate and with the same cutlery between siblings or between parents and preschoolers (Table 1). According to the food record, 31 (73.80\%) preschoolers usually eat snacks between meals, such as sandwich cookies, candies, and milk-based drinks. Out of these 31 preschoolers, $21(67.74 \%)$ usually eat snacks 3 to 4 times between main meals (breakfast, morning snack, lunch, afternoon snack and dinner) (Table 2).

In the main meals such as lunch and dinner, portions of rice and beans are offered to the preschooler, accompanied by some type of protein $(\mathrm{n}=40)$ and only $08(19.04 \%)$ of the preschoolers consume greens and vegetables for lunch and/or dinner. Among parents, 06 (14.28\%) stated that the preschooler already drinks soda during meals and $19(45.23 \%)$ of them drink powdered juice sweetened by the parents.

Among the preschoolers who use a bottle, only 03 (10.00\%) drink milk without added sugars and/or chocolate. And the average frequency of daily brushing is twice, with the preschooler brushing their teeth by themselves in all cases (Table 2).

The average CFU/ml of S. mutans found in the saliva of mothers was 974421 and that of preschoolers was 135341.9 $\mathrm{CFU} / \mathrm{ml}$ of $S$. mutans.

Thus, Tables 1 and 2 show that $35.71 \%$ of the preschoolers shared kitchen utensils, $57.14 \%$ attended day care or school, $95.24 \%$ had a habit of brushing their teeth, $64.29 \%$ of preschoolers were weaned early. Additionally, it was found that $66.67 \%$ of mothers and $09.52 \%$ of preschoolers had caries, and that the adherent extracellular polymer - which is important for cariogenicity - was present in $61.90 \%$ of mothers and $09.52 \%$ of preschoolers. However, there was no relationship between sharing kitchen utensils between the preschooler and family members, preschoolers who attend school, the preschooler's tooth brushing, weaning before 6 months, the presence of active caries in the mother and preschooler and the presence of extracellular polymer in the CFU of $S$. mutans collected from the mother's saliva (61.90\%), with the variable presence of extracellular polymer in the CFU of $S$. mutans collected from the preschooler's saliva $(09.52 \%)$. 
Table 1. Logistic regression of the variables: sharing kitchen utensils between the preschooler and family members, preschooler attends school, brushing the preschooler's teeth, weaning before 6 months, presence of active caries in the mother and preschooler and presence of extracellular polymer in the CFU of S. mutans collected from the mother's saliva, with the variable presence of extracellular polymer in the CFU of S. mutans collected from the preschooler's saliva. Brazil, 2020.

\begin{tabular}{llll}
\hline Variables & $<0.05$ & Odds ratio & Confidence Interval \\
\hline Sharing kitchen utensils & 0.710 & 0.638 & $0.06-06.82$ \\
\hline Attends school (preschooler) & 0.212 & 0.222 & $0.02-02.36$ \\
\hline Habit of brushing teeth (preschooler) & 0.938 & 8148,984 & $0.00-\infty$ \\
\hline Weaning before 6 months & 0.710 & 1,565 & $0.15-16.72$ \\
\hline Presence of caries (preschooler) & 0.294 & 1.519 & $0.69-03.32$ \\
\hline Presence of caries (mother) & 0.711 & 1,560 & $0.15-16.53$ \\
\hline Presence of extracellular polymer (mother) & 0.810 & $13,969,688$ & $0.00-\infty$ \\
\hline
\end{tabular}

Source: Elaborated by the author (2020). 
Table 2. Numerical distribution, percentage and Fisher's Exact Test, of the variables presence of caries in the mother, preschooler attends school, sharing kitchen utensils between the preschooler and family members, weaning before 6 months, using a bottle with the variable presence of caries in the preschooler. Brazil, 2020.

\begin{tabular}{llll}
\hline Presence of caries in the preschooler & & \\
\hline Yes & No & Total & $<0.05$ \\
05 & 37 & 42 & \\
$(11.90 \%)$ & $(88.10 \%)$ & $(100 \%)$ & \\
\hline
\end{tabular}

\begin{tabular}{|c|c|c|c|c|c|}
\hline Variables & $\mathrm{n}$ & $\%$ & & & \\
\hline \multicolumn{6}{|c|}{ Presence of caries in the mother } \\
\hline & $\mathrm{n}$ & 28 & 14 & 42 & \multirow[t]{2}{*}{0.312} \\
\hline & $\%$ & 66.67 & 33.33 & 100.00 & \\
\hline \multicolumn{6}{|c|}{ Preschooler attends school } \\
\hline & $\mathrm{n}$ & 24 & 18 & 42 & \multirow[t]{2}{*}{0.635} \\
\hline & $\%$ & 57.14 & 42.86 & 100.00 & \\
\hline
\end{tabular}

Shares kitchen utensils

$\begin{array}{lllll}\mathrm{n} & 15 & 27 & 42 & 1.000 \\ \% & 35.71 & 64.29 & 100.00 & \end{array}$

\begin{tabular}{|c|c|c|c|c|c|}
\hline \multicolumn{6}{|l|}{ Weaning before 6 months } \\
\hline & $\mathrm{n}$ & 27 & 15 & 42 & 0.046 \\
\hline & $\%$ & 64.29 & 35.71 & 100.00 & \\
\hline \multirow[t]{2}{*}{ Bottle use } & $\mathrm{n}$ & 30 & 12 & 42 & \\
\hline & $\%$ & 71.43 & 28.57 & 100.00 & 0.018 \\
\hline \multicolumn{6}{|c|}{ Consumption of sugary foods } \\
\hline \multirow[t]{2}{*}{ between meals } & $\mathrm{n}$ & 31 & 11 & 42 & \\
\hline & $\%$ & 73.81 & 26.19 & 100.00 & 0.302 \\
\hline \multirow[t]{2}{*}{ Toothbrushing } & $\mathrm{n}$ & 40 & 02 & 42 & \\
\hline & $\%$ & 95.24 & 04.76 & 100.00 & 1.000 \\
\hline
\end{tabular}

Source: Elaborated by the author (2020).

\section{Discussion}

For the infant's best immune, physical, mental and emotional development, breast milk is still the best option (Brazil, 2019; Marques et al., 2020; Rocha et al., 2010; Sousa et al., 2021; World Health Organization, 2001). It offers a protective factor against tooth decay (Moynihan et al., 2019; Tham et al., 2015) that can be mediated through the establishment of a healthy oral microbiome in infants, through exposure to breastfeeding and contact with microbiomes of the mother 's skin, milk and mouth (Tham et al., 2015). Although caries is a multifactorial disease and subject to changes due to risk factors, such as socioeconomic status, education, oral health and maternal smoking, primigravida, sugars in the diet, oral hygiene and exposure to fluoride (Moynihan et al., 2019), breastfeeding still plays a fundamental role in the prevention of caries, as it contains 
lactobacilli and specific breastmilk substances, including human casein and secretory $\operatorname{IgA}$, which inhibits the growth and adhesion of cariogenic bacteria, especially oral streptococci (Holgerson et al., 2013), so early weaning may be associated with the appearance of caries in childhood due to the use of bottle with sweetened milk, as observed in this study.

A balanced diet, even in the first years of life, is crucial for the individual's health, with childhood being a favorable period to encourage good eating habits (Arikpo et al., 2018; Brazil, 2019; Tully et al., 2019). Recurrent bottle use can develop malocclusions in preschoolers (Franzin et al., 2020; Rocha et al., 2013) and, depending on the content and frequency of ingestion, induces the occurrence or helps in the formation of dental caries (Barone et al., 2018; Feldens et al., 2018; Gibson \& Williams, 1999; Marshall et al., 2005; Nicksic et al., 2018), in addition to favoring the development of diseases such as obesity, increased blood glucose and other morbidities (Cinar, Christensen, \& Hede, 2011; Limaet al., 2020; Moreno et al., 2013).

The addition of sugar and extremely sweetened chocolate powders in preschooler's drinks and bottles is a common practice in families' daily lives and becomes increasingly precocious, contrary to the recommendations of competent agencies, such as the World Health Organization (Bernabé et al., 2020; Fidler et al., 2017; World Health Organization, 2015). The results of this work corroborate the works mentioned above, as $90 \%$ of the bottles had added sugar, making the sweetened drink an even greater factor of cariogenicity (Tinanoff, \& Palmer, 2000; Mohebbi et al., 2008; Moynihan et al., 2019) that resulted in the association of bottle use with the presence of caries in preschoolers at 30 months of age.

At pre-school age, sedimentation of eating habits is important, as it is the beginning of a transition phase in which the preschooler begins to become more independent and less open to new flavors and foods (food neophobia), being able to acquire an unpredictable and variable eating behavior, such as wanting a single type of food or not enjoying their favorite food (Bell et al., 2018; Sociedade Brasileira de Pediatria, 2012). As a result, parents/guardians tend to take a wrong approach and offer sweets as a reward if the child eats some food they normally don't want to eat. This type of conduct reinforces bad eating habits (Bell et al., 2018; Sociedade Brasileira de Pediatria, 2012). For the sedimentation of eating habits to occur, it is necessary to establish fixed meal times (breakfast, morning snack, lunch, afternoon snack and dinner) and avoid offering food out of hours or letting the preschooler eat whenever they wish (Bell et al., 2018; Sociedade Brasileira de Pediatria, 2012). This information was passed on to the parents and/or guardians who were part of this study as a way of educating and contributing to the improvement of the general and oral health of those involved.

The interest in sweets in this age group is something common, and total prohibition can cause the preschooler to crave it even more. Ideally, the family should explain in easy terms the benefits and harms of each type of food, in addition to having healthy habits to allow preschoolers to learn by imitation (Arikpo et al., 2018; Bell et al., 2018; Norlyk, Larsen, \& Kronborg, 2019; Sociedade Brasileira de Pediatria, 2012; Tully et al., 2019). In this work, many preschoolers ate outside mealtimes, always extremely sugary foods, and drinking soda and artificially sweetened juice during meals was also widely reported by parents. Although the frequency of ingestion of sugary foods is not associated with caries breakdowns in this study, these habits are bad for the preschooler's health and negatively affects an adequate food sedimentation, necessary in this age group, in addition to causing short-term and long-term health problems, such as dental caries, obesity, diabetes, cardiovascular problems, anemia, high blood pressure, malnutrition, osteoporosis, among others (Barone et al., 2018; Cinar, Christensen, \& Hede, 2011; Lima et al., 2020; Moreno et al., 2013; Verduci et al., 2019).

As previously mentioned, caries is a disease with multifactorial causes (Barone et al., 2018; Cinar, Christensen, \& Hede, 2011; Gibson \& Williams, 1999; Kassebaum et al., 2017; Marshall et al., 2005; Mattos-Graner et al., 2001) and the vertical transmission of the microorganism $S$. mutans, added to other factors, may predispose preschoolers to dental caries. Within the family environment, this transmission occurs easily through sharing kitchen utensils, kisses, toothbrushes, etc. (Barone et al., 2018; Cinar, Christensen, \& Hede, 2011; Gibson \& Williams, 1999; Kassebaum et al., 2017; Marshall et al., 
2005; Mattos-Graner et al., 2001). In the current study, there was no relationship between these factors and the appearance of caries breakdowns in the preschooler or the presence of extracellular polymer in the CFU of $S$. mutans found in the preschooler's saliva. However, this does not mitigate the family's responsibility to take care and, when financially possible, propose the individualization of the use of personal belongings among the members of the household (Liu et al.,2007; MattosGraner et al., 2001). The school is also a place where there is a wide spread of microorganisms that cause diseases, such as cariogenic bacteria, which can be propagated by the shared use of mugs, cups, cutlery among preschoolers and between caregivers and preschoolers (Liu et al., 2007; Mattos-Graner et al., 2001). However, in this work, the fact that preschoolers attend school was not associated or related to the presence of caries and extracellular polymer. And it is important to emphasize the importance of maintaining hygiene standards and encouraging good habits among preschoolers in schools.

In addition to diet, toothbrushing daily and after each meal should be encouraged early to prevent caries (Chomitz et al., 2019; Paglia, 2019). At birth, it is already recommended to clean the infant's mouth with gauze or soft cloth after feedings and, as soon as the first teeth appear, start using appropriate brushes for each age group (Chomitz et al., 2019; Nishide et al., 2018; Paglia, 2019). Nevertheless, the present study did not show the relationship between toothbrushing and the presence of caries. It is known that when brushing the dental surfaces, the mechanical action of the brush bristles disorganizes the biofilm, reducing the adhesion of microorganisms to the dental enamel, assisting in the mineralization process and decreasing the possibility of initiating the caries breakdown (Arweiler \& Netuschil, 2016). For brushing to be efficient, it is important that those responsible for the preschooler perform brushing at least once a day and supervise the rest, which did not occur in this work, since all preschoolers brushed their teeth without adult supervision.

The presence of extracellular polymer in S. mutans colonies may be related to individuals with active caries (Bowen, \& Koo, 2011; Hwang et al., 2015). This bacterial pathogen can quickly assist in the formation of cariogenic biofilm when frequently exposed to sucrose, which is used by glycosyltransferase to produce adherent extracellular glycans, which in turn increase the local accumulation of microorganisms and facilitate the adhesion of cariogenic microorganisms on the tooth surface, being critical in the development of dental caries (Bowen, \& Koo, 2011; Hwang et al., 2015). In most saliva samples, extracellular polymer was not observed in the $S$. mutans colonies and those that produced the polymer were not related to the other studied variables.

In this work, as already mentioned, some of the main causes associated with the appearance of carious lesions, such as a sugary diet, oral hygiene habits, sharing kitchen utensils (vertical transmission of S. mutans), did not show any association, and the causes for this are diverse, such as time (amount of time that habits are present), virulence factor of bacteria causing caries, competition from microorganisms for the environment, among others (Barone et al., 2018; Cinar, Christensen, \& Hede, 2011; Gibson \& Williams, 1999; Kassebaum et al., 2017; Liu et al., 2007; Marshall et al., 2005; Mattos-Graner et al., 2001). The factors mentioned above are predisposing to the formation of caries, highlighting the importance of preventive actions and health promotion from the beginning of life (Arikpo et al., 2018; Colley et al., 2019; Nicksic et al., 2018; Paglia 2019). Information on oral hygiene and healthier diet options were passed on to parents / guardians to improve oral health and general of the research participants.

One of the limitations of the study is the non-approach to the food menu offered in the schools that the preschoolers attended since it would address a greater detail of the diet. It is suggested to include these variables in future works, for a better association of the diet with the onset of caries in early childhood.

The food is directly related to general and oral health. It is important for families to incorporate healthy habits in their daily lives and perpetuate them from one generation to the next (Arikpo et al., 2018; Bell et al., 2018; Brazil, 2019; Sociedade Brasileira de Pediatria, 2012; Norlyk, Larsen, \& Kronborg, 2019; Tully et al., 2019). Ensuring a healthy lifestyle, in addition to 
being a child's right, is the responsibility of their parents/guardians, health professionals and educators (Chomitz et al., 2019; Nishide et al., 2018; Paglia, 2019).

\section{Conclusion}

Based on the results found in this study, it was concluded that eating habits, such as early weaning and bottle use, were associated with the presence of caries.

There was no association between microbiological and behavioral aspects that affect oral health and the consumption of sugary foods between meals with the presence of caries in preschoolers.

\section{Acknowledgments}

This work was carried out with the support of the Coordination for the Improvement of Higher Education Personnel (CAPES) Financing Code 001

\section{References}

Arikpo, D., Edet, E. S., Chibuzor, M. T., Odey, F., \& Caldwell, D. M. (2018). Educational interventions for improving primary caregiver complementary feeding practices for children aged 24 months and under. The Cochrane database of systematic reviews,5(5), CD011768. https://doi.org/10.1002/14651858.CD011768.pub2

Arweiler, N. B., \& Netuschil, L. (2016). The Oral Microbiota. Advances in experimental medicine and biology, 902, 45-60. https://doi.org/10.1007/978-3-31931248-4_4

Barone, A., Giannoni, M., Ortu, E., Monaco, A., \& Pietropaoli, D. (2018). Short-term and Long-lasting Effects of Hypo-Cariogenic Dietary Advice and Oral Care on Oral Flora: a Randomised Clinical Trial. Oral health \& preventive dentistry, 16(4), 315-325.

Bell, L. K., Jansen, E., Mallan, K., Magarey, A. M., \& Daniels, L. (2018). Poor dietary patterns at 1-5 years of age are related to food neophobia and breastfeeding duration but not age of introduction to solids in a relatively advantaged sample. Eating behaviors, 31, 28-34. 0

Bernabé, E., Ballantyne, H., Longbottom, C., \& Pitts, N. B. (2020). Early Introduction of Sugar-Sweetened Beverages and Caries Trajectories from Age 12 to 48 Months. Journal of dental research, 99(8), 898-906. https://doi.org/10.1177/0022034520917398.

Bowen, W. H., \& Koo, H. (2011). Biology of Streptococcus mutans-derived glucosyltransferases: role in extracellular matrix formation of cariogenic biofilms. Caries research, 45(1), 69-86. https://doi.org/10.1159/000324598

Brazil (2012). Resolution no. 466, of December 12. Approves guidelines and regulatory standards for research involving human beings. https://bvsms.saude.gov.br/bvs/saudelegis/cns/2013/res0466_12_12_2012.html

Brazil. (2019). Ministry of Health. Secretariat of Primary Health Care. Department of Health Promotion. Food guide for Brazilian children under 2 years old. Ministry of Health.

Chomitz, V. R., Park, H. J., Koch-Weser, S., Chui, K., Sun, L., Malone, M. E., et al. (2019). Modifying dietary risk behaviors to prevent obesity and dental caries in very young children: results of the Baby Steps to Health pediatric dental pilot. Journal of Public Health Dentistry, 79, 207-214. https://doi.org/10.1111/jphd.12311

Cinar, A. B., Christensen, L. B., \& Hede, B. (2011). Clustering of obesity and dental caries with lifestyle factors among Danish adolescents. Oral health \& preventive dentistry, $9(2), 123-130$.

Colley, P., Myer, B., Seabrook, J., \& Gilliland, J. (2019). The Impact of Canadian School Food Programs on Children's Nutrition and Health: A Systematic Review. Canadian journal of dietetic practice and research : a publication of Dietitians of Canada = Revue canadienne de la pratique et de la recherche en dietetique : une publication des Dietetistes du Canada, 80(2), 79-86. https://doi.org/10.3148/cjdpr-2018-037

Feldens, C. A., Rodrigues, P. H., de Anastácio, G., Vítolo, M. R., \& Chaffee, B. W. (2018). Feeding frequency in infancy and dental caries in childhood: a prospective cohort study. International dental journal, 68(2), 113-121. https://doi.org/10.1111/idj.12333

Fidler Mis, N., Braegger, C., Bronsky, J., Campoy, C., Domellöf, M., Embleton, N. D., et al. (2017). Sugar in infants, children and adolescents: a position paper of the European Society for Paediatric Gastroenterology, Hepatology and Nutrition Committee on Nutrition. Journal of Pediatric Gastroenterology and Nutrition, 65, 681-696. https://doi.org/10.1097/MPG.0000000000001733

Franzin, L. C. S., Pereira, L. A. B., Saab, F. J., Santin, G. C., \& Freitas, K. M. S. (2020). Factors associated with early weaning in babies seen at a health unit in southern Brazil. Research, Society and Development, 9, e79091110327. https://doi.org/10.33448/rsd-v9i11.10327

Gibson, S., \& Williams, S. (1999). Dental caries in pre-school children: associations with social class, toothbrushing habit and consumption of sugars and sugar-containing foods. Further analysis of data from the National Diet and Nutrition Survey of children aged 1.5-4.5 years. Caries Research, 33, 101-113. https://doi.org/10.1159/000016503 
Gorgulho, B. M., Pot, G. K., Sarti, F. M., \& Marchioni, D. M. (2016). Indices for the assessment of nutritional quality of meals: a systematic review. The British Journal of Nutrition, 115, 2017-2024. https://doi.org/10.1017/S0007114516000994

Holgerson, P. L., Vestman, N. R., Claesson, R., Ohman, C., Domellöf, M., Tanner, A. C., et al. (2013). Oral microbial profile discriminates breast-fed from formula-fed infants. Journal of Pediatric Gastroenterology and Nutrition, 56, 127-136. https://doi.org/10.1097/MPG.0b013e31826f2bc6

Hwang, G., Marsh, G., Gao, L., Waugh, R., \& Koo, H. (2015). Binding Force Dynamics of Streptococcus mutans-glucosyltransferase B to Candida albicans. Journal of Dental Research, 94, 1310-1317. https://doi.org/10.1177/0022034515592859

Kassebaum, N. J., Smith, A., Bernabé, E., Fleming, T. D., Reynolds, A. E., Vos, T., et al. (2017). Global, regional, and national prevalence, incidence, and disability-adjusted life years for oral conditions for 195 countries, 1990-2015: a systematic analysis for the global burden of diseases, injuries, and risk factors. Journal of Dental Research, 96, 380-387. https://doi.org/10.1177/0022034517693566

Kolodziejczyk, J. K., Merchant, G., \& Norman, G. J. (2012). Reliability and validity of child/adolescent food frequency questionnaires that assess foods and/or food groups. Journal of Pediatric Gastroenterology and Nutrition, 55, 4-13. https://doi.org/10.1097/MPG.0b013e318251550e

Korkalo, L., Vepsäläinen, H., Ray, C., Skaffari, E., Lehto, R., Hauta-Alus, H. H., et al. (2019). Parents' reports of preschoolers' diets: relative validity of a food frequency questionnaire and dietary patterns. Nutrients, 11, 159. https://doi.org/10.3390/nu11010159

Lima, A. T. A., Lima, C. L. S., Barboza, A. A. A., Lima, V. S., Viana, K. K. G., \& Lira, S. M. (2020). Influência da introdução precoce de alimentos no desenvolvimento da obesidade infantil: uma revisão da literatura. Research, Society and Development, 9, e56984925. https://doi.org/10.33448/rsd-v9i8.4925

Liu, Y., Zou, J., Shang, R., \& Zhou, X. D. (2007). Genotypic diversity of Streptococcus mutans in 3- to 4-year-old Chinese nursery children suggests horizontal transmission. Archives of Oral Biology, 52, 876-881. https://doi.org/10.1016/j.archoralbio.2007.03.004

Marques, V. G. P. S., Silva, M. P. B., Silva, P. I. O., Alves, R. S. S., Jesus, G. L. S., Sousa, A. B., et al. (2020). Breastfeeding: importance and benefits of breastfeeding. Research, Society and Development, 9(10), e2299108405. https://doi.org/10.33448/rsd-v9i10.8405

Marshall, T. A., Broffitt, B., Eichenberger-Gilmore, J., Warren, J. J., Cunningham, M. A., \& Levy, S. M. (2005). The roles of meal, snack, and daily total food and beverage exposures on caries experience in young children. Journal of Public Health Dentistry, 65, 166-173. https://doi.org/10.1111/j.17527325.2005.tb02807.x

Mattos-Graner, R. O., Li, Y., Caufield, P. W., Duncan, M., \& Smith, D. J. (2001). Genotypic diversity of mutans streptococci in Brazilian nursery children suggests horizontal transmission. Journal of Clinical Microbiology, 39, 2313-2316. https://doi.org/10.1128/JCM.39.6.2313-2316.2001

Mohebbi, S. Z., Virtanen, J. I., Vahid-Golpayegani, M., \& Vehkalahti, M. M. (2008). Feeding habits as determinants of early childhood caries in a population where prolonged breastfeeding is the norm. Community Dentistry and Oral Epidemiology, 36, 363-369. https://doi.org/10.1111/j.1600-0528.2007.00408.x

Moreno, L. A., Bel-Serrat, S., Santaliestra-Pasías, A. M., \& Rodríguez, G. (2013). Obesity prevention in children. World Review of Nutrition and Dietetics, 106, 119-126. https://doi.org/10.1159/000342560

Moynihan, P., Tanner, L. M., Holmes, R. D., Hillier-Brown, F., Mashayekhi, A., Kelly, S., et al. (2019). Systematic review of evidence pertaining to factors that modify risk of early childhood caries. JDR Clinical and Translational Research, 4, 202-216. https://doi.org/10.1177/2380084418824262

Nicksic, N. E., Massie, A. W., Byrd-Williams, C. E., Kelder, S. H., Sharma, S. V., Butte, N. F., et al. (2018). Dietary intake, attitudes toward healthy food, and dental pain in low-income youth. JDR Clinical and Translational Research, 3, 279-287. https://doi.org/10.1177/2380084418774039

Nishide, R., Mizutani, M., Tanimura, S., Kudo, N., Nishii, T., \& Hatashita, H. (2018). Homecare protective and risk factors for early childhood caries in Japan. Environmental Health and Preventive Medicine, 23, 57. https://doi.org/10.1186/s12199-018-0746-8

Norlyk, A., Larsen, J. S., \& Kronborg, H. (2019). Infants' transition from milk to solid foods - the lived experiences of first-time parents. International Journal of Qualitative Studies on Health and Well-Being, 14, 1693483. https://doi.org/10.1080/17482631.2019.1693483

Paglia, L. (2019). Oral prevention starts with the mother. European Journal of Paediatric Dentistry, 20, 173. https://doi.org/10.23804/ejpd.2019.20.03.01

Rocha, N. B., Garbin, A. J. I., Garbin, C. A. S., \& Moimaz, S. A. S. (2010). O ato de amamentar: um estudo qualitativo. Physis: Revista de Saúde Coletiva, 20, 1293-1305. https://doi.org/10.1590/S0103-73312010000400012

Rocha, N. B., Garbin, A. J. I., Garbin, C. A. S., Saliba, O., \& Moimaz, S. A. S. (2013). Longitudinal study on the practice of breastfeeding and factors associated with early weaning. Brazilian Research in Pediatric Dentistry and Integrated Clinic, 13, 337-342. https://doi:10.4034/PBOCI.2013.134.06

Sociedade Brasileira de Pediatria. (2012). Guidance manual for feeding infants, preschoolers, schoolchildren, adolescents and at school (3rd ed.). Brazilian Society of Pediatrics.

Sousa, F. L. L., Alves, R. S. S., Leite, A. C., Silva, M. P. B., Veras, C. A., Santos, R. C. A., et al. (2021). Benefits of breastfeeding for women and newborns. Research, Society and Development, 10, e12710211208. https://doi.org/10.33448/rsd-v10i2.11208

Tham, R., Bowatte, G., Dharmage, S. C., Tan, D. J., Lau, M. X., Dai, X., et al. (2015). Breastfeeding and the risk of dental caries: a systematic review and meta-analysis. Acta Paediatrica, 104, 62-84. https://doi.org/10.1111/apa.13118

Tinanoff, N., \& Palmer, C. A. (2000). Dietary determinants of dental caries and dietary recommendations for preschool children. Journal of Public Health Dentistry, 60, 197-209. https://doi.org/10.1111/j.1752-7325.2000.tb03328.x

Tully, L., Allen-Walker, V., Spyreli, E., McHugh, S., Woodside, J. V., Kearney, P. M., et al. (2019). Solid advice: complementary feeding experiences among disadvantaged parents in two countries. Maternal \& Child Nutrition, 15, e12801. https://doi.org/10.1111/mcn.12801 
Research, Society and Development, v. 10, n. 5, e34410514753, 2021

(CC BY 4.0) | ISSN 2525-3409 | DOI: http://dx.doi.org/10.33448/rsd-v10i5.14753

Verduci, E., Banderali, G., Montanari, C., Berni Canani, R., Cimmino Caserta, L., Corsello, G., et al. (2019). Childhood dietary intake in italy: the epidemiological "My Food Diary" survey. Nutrients, 11, 1129. https://doi.org/10.3390/nu11051129

Weker, H., Brudnicka, E., Barańska, M., Rowicka, G., Strucińska, M., Więch, M., et al. (2019). Dietary patterns of children aged 1-3 years in Poland in two population studies. Annals of Nutrition \& Metabolism, 75, 66-76. https://doi.org/10.1159/000501422

World Health Organization. (2001). The World Health Organization's infant feeding recommendation. World Health Organization.

World Health Organization. (2015). New evidence cuts ideal sugar consumption in half. World Health Organization. 